Supporting Information for

\title{
P,S-Containing Hybrid Calixphyrins: Promising Mixed-Donor Ligands for Visible and Efficient Palladium Catalysts
}

\author{
Yoshihiro Matano,* Tooru Miyajima, Takashi Nakabuchi, Hiroshi Imahori, Noriaki Ochi, and \\ Shigeyoshi Sakaki \\ Department of Molecular Engineering, Graduate School of Engineering, Kyoto University, Nishikyo- \\ ku, Kyoto 615-8510, Japan \\ matano@scl.kyoto-u.ac.jp \\ FAX: 81-75-383-2571
}

Contents:

General:

SI-2

Synthesis and Characterization of $P, N_{2}, S$-Hybrid Calixphyrins:

SI-2

Figures S1 S9:

SI-5

Density Functional Theory Calculations on Model Complexes and Figure S10: $\quad$ SI-9 


\section{General}

All melting points are uncorrected. ${ }^{1} \mathrm{H},{ }^{13} \mathrm{C}\left\{{ }^{1} \mathrm{H}\right\}$, and ${ }^{31} \mathrm{P}\left\{{ }^{1} \mathrm{H}\right\}$ NMR spectra were recorded using $\mathrm{CDCl}_{3}$ as the solvent unless otherwise noted. The ${ }^{1} \mathrm{H}$ NMR spectra of 3-7 are shown in Figures S4-S8. Chemical shifts are reported as the relative value vs. tetramethylsilane $\left({ }^{1} \mathrm{H}\right.$ and $\left.{ }^{13} \mathrm{C}\right)$ and phosphonic acid $\left({ }^{31} \mathrm{P}\right)$. MALDI-TOF mass spectra were measured using CHCA as a matrix. IR spectra were observed as $\mathrm{KBr}$ pellets. All solvents were distilled from sodium benzophenone ketyl (ether, THF) or calcium hydride $\left(\mathrm{CH}_{2} \mathrm{Cl}_{2}\right.$, toluene) before use. All the reactions were performed under an argon or nitrogen atmosphere. Column chromatography was performed on silica gel or on a fast flow liquid chromatography system fitted with a silica gel column. Compounds $\mathbf{1}^{1}$ and $\mathbf{2}^{2}$ were prepared according to the reported procedures.

\section{Synthesis and Characterization of $P, N_{2}, S$-Hybrid Calixphyrins}

$\sigma^{4}$-Hybrids 3 and 4: A solution of $1(530 \mathrm{mg}, 1.2 \mathrm{mmol})$ and 2 (360 mg, $\left.1.2 \mathrm{mmol}\right)$ in $\mathrm{CH}_{2} \mathrm{Cl}_{2}(600$ $\mathrm{mL})$ was bubbled with $\mathrm{N}_{2}$ for $30 \mathrm{~min}$, and $\mathrm{BF}_{3} \bullet \mathrm{OEt}_{2}(0.15 \mathrm{~mL}, 1.2 \mathrm{mmol})$ was added to the solution. After stirring for $2 \mathrm{~h}$ at room temperature, DDQ (600 mg, $2.6 \mathrm{mmol}$ ) was added to the mixture. After stirring for an additional $1 \mathrm{~h}$, a saturated aqueous $\mathrm{Na}_{2} \mathrm{CO}_{3}$ solution $(200 \mathrm{~mL}$ ) was poured into the reaction mixture. The organic phase was washed with aq $\mathrm{Na}_{2} \mathrm{CO}_{3}(200 \mathrm{~mL} \times 3)$ and brine $(200 \mathrm{~mL})$, dried over $\mathrm{Na}_{2} \mathrm{SO}_{4}$, and evaporated. The products were subjected to silica gel column chromatography (hexane $\left./ \mathrm{CH}_{2} \mathrm{Cl}_{2} / \mathrm{AcOEt}=10 / 3 / 1\right)$. The orange fraction $\left(R_{\mathrm{f}}=0.5\right)$ and the wine red fraction $\left(R_{\mathrm{f}}=0.3\right)$ were collected, evaporated, and washed with $\mathrm{MeOH}$ to give 4 as a reddish orange solid (40 mg, 5\%) and $\mathbf{3}$ as a red solid (200 mg, 24\%), respectively.

3: $\mathrm{Mp} 190{ }^{\circ} \mathrm{C}(\mathrm{dec}) ;{ }^{1} \mathrm{H} \mathrm{NMR}\left(\mathrm{CDCl}_{3}, 400 \mathrm{MHz}\right) \delta 1.45$ (s, 6H), $1.56(\mathrm{~s}, 6 \mathrm{H}), 1.90-2.15(\mathrm{~m}, 2 \mathrm{H})$, 2.35-2.60 (m, 4H), $6.55(\mathrm{~d}, 2 \mathrm{H}, J=4.4 \mathrm{~Hz}), 6.66(\mathrm{~d}, 2 \mathrm{H}, J=4.4 \mathrm{~Hz}), 6.64(\mathrm{~s}, 2 \mathrm{H}), 7.35-7.50(\mathrm{~m}$,

\footnotetext{
${ }^{1}$ (a) Matano, Y.; Nakabuchi, T.; Miyajima, T.; Imahori, H. Organometallics 2006, 25, 3105. (b) Matano, Y.; Miyajima, T.; Nakabuchi, T.; Matsutani, Y.; Imahori, H. J. Org. Chem. 2006, 71, 5792. ${ }^{2}$ Ulman, A.; Manassen, J. J. Am. Chem. Soc. 1975, 97, 6540.
} 
$10 \mathrm{H}), 7.40-7.55(\mathrm{~m}, 3 \mathrm{H}), 8.14(\mathrm{~m}, 2 \mathrm{H}) ;{ }^{13} \mathrm{C}\left\{{ }^{1} \mathrm{H}\right\} \mathrm{NMR}\left(\mathrm{CDCl}_{3}, 68 \mathrm{MHz}\right) \delta 24.8,24.9,26.0,28.4,30.7$, $30.9,41.7,41.8,125.6,127.5,128.2,128.3,128.5,130.4,130.6,130.8,133.3,133.8,134.4,136.0$, 138.3, 141.8, 152.5, 152.6, 180.4; ${ }^{31} \mathrm{P}\left\{{ }^{1} \mathrm{H}\right\} \mathrm{NMR}\left(\mathrm{CDCl}_{3}, 162 \mathrm{MHz}\right) \delta+67.9 ; \mathrm{UV} / \mathrm{Vis}\left(\mathrm{CH}_{2} \mathrm{Cl}_{2}\right) \lambda_{\max }(\varepsilon)$ : 330 (34200), 496 (18400), 524 (sh, 15700); MS (FAB) $m / z, 703\left([\mathrm{M}+\mathrm{H}]^{+}\right)$. HRMS: Calcd for $\mathrm{C}_{45} \mathrm{H}_{39} \mathrm{~N}_{2} \mathrm{PS}_{2}\left(\mathrm{M}^{+}\right), 702.2292$; Found, 702.2293.

4: Mp 218-220 ${ }^{\circ} \mathrm{C} ;{ }^{1} \mathrm{H}$ NMR (toluene- $\left.d_{8}, 343 \mathrm{~K}, 400 \mathrm{MHz}\right) \delta 1.40-1.50$ (m, 2H), 1.45 (s, 6H), 1.61 (s, $6 \mathrm{H}), 1.82-2.00(\mathrm{~m}, 4 \mathrm{H}), 5.97(\mathrm{~m}, 2 \mathrm{H}), 6.02(\mathrm{~m}, 2 \mathrm{H}), 6.51(\mathrm{~s}, 2 \mathrm{H}), 7.08-7.20(\mathrm{~m}, 9 \mathrm{H}), 7.28-7.34(\mathrm{~m}$, 4H), $7.97(\mathrm{~m}, 2 \mathrm{H}), 10.06(\mathrm{~m}, 2 \mathrm{H}) ;{ }^{31} \mathrm{P}\left\{{ }^{1} \mathrm{H}\right\}$ NMR (toluene- $\left.d_{8}, 343 \mathrm{~K}, 162 \mathrm{MHz}\right) \delta+70.0$; IR $(\mathrm{KBr}) v_{\max }$ $3297(\mathrm{NH}) \mathrm{cm}^{-1}$; UV/Vis $\left(\mathrm{CH}_{2} \mathrm{Cl}_{2}\right) \lambda_{\max }(\varepsilon)$ : 306 (19900), 508 (28000); MS (FAB) m/z $704\left(\mathrm{M}^{+}\right)$. Anal. calcd for $\mathrm{C}_{45} \mathrm{H}_{41} \mathrm{~N}_{2} \mathrm{PS}_{2}$ : C, 76.67; H, 5.86; N, 3.97; P, 4.39. Found: C, 76.43; H, 5.95; N, 3.69; P, 4.12.

$\sigma^{3}$-Hybrids 5 and 6: $\mathrm{P}\left(\mathrm{NMe}_{2}\right)_{3}(0.13 \mathrm{~mL}, 0.71 \mathrm{mmol})$ was added to a toluene solution $(20 \mathrm{~mL})$ containing 3 (200 mg, $0.28 \mathrm{mmol}$ ). After stirring under reflux for $20 \mathrm{~h}$, the mixture was concentrated under reduced pressure, and the residue was subjected to silica gel column chromatography (hexane $\left./ \mathrm{CH}_{2} \mathrm{Cl}_{2} / \mathrm{AcOEt}=15 / 5 / 1\right)$. The purple fraction $\left(R_{\mathrm{f}}=0.3\right)$ was collected and washed with $\mathrm{MeOH}$ to give 5 as a wine red solid $(125 \mathrm{mg}, 66 \%)$. A small amount of side-product $\mathbf{6}$ was also obtained as an orange solid $\left(R_{\mathrm{f}}=0.5,9 \mathrm{mg}, 5 \%\right)$.

5: $\mathrm{Mp} 185^{\circ} \mathrm{C}(\mathrm{dec}) ;{ }^{1} \mathrm{H}$ NMR $\left(\mathrm{CDCl}_{3}, 400 \mathrm{MHz}\right) \delta 1.33(\mathrm{~s}, 6 \mathrm{H}), 1.52(\mathrm{~s}, 6 \mathrm{H}), 2.00-2.10(\mathrm{~m}, 1 \mathrm{H}), 2.24$ (m, 1H), 2.20-2.32 (m, 2H), 2.45-2.55 (m, 2H), $6.60(\mathrm{~s}, 2 \mathrm{H}), 6.60(\mathrm{~d}, 2 \mathrm{H}, J=4.5 \mathrm{~Hz}), 6.64(\mathrm{~d}, 2 \mathrm{H}, J=$ 4.5 Hz), 7.26-7.30 (m, 3H), 7.32-7.50 (m, 10H), $7.57(\mathrm{~m}, 2 \mathrm{H}) ;{ }^{13} \mathrm{C}\left\{{ }^{1} \mathrm{H}\right\} \mathrm{NMR}\left(\mathrm{CDCl}_{3}, 100 \mathrm{MHz}\right) \delta$ 26.5, 26.6, 28.7, 28.8, 29.5, 41.6, 41.8, 126.0, 127.4, 127.8, 127.9, 128.0, 128.4, 130.4, 130.5, 130.6, $133.5,134.1,134.4,135.3,135.5,138.1,140.9,141.3,152.2,152.7,155.5,155.6,182.4 ;{ }^{31} \mathrm{P}\left\{{ }^{1} \mathrm{H}\right\}$ $\mathrm{NMR}\left(\mathrm{CDCl}_{3}, 162 \mathrm{MHz}\right) \delta+26.7$; UV/Vis $\left(\mathrm{CH}_{2} \mathrm{Cl}_{2}\right) \lambda_{\max }(\varepsilon): 326$ (42600), 493 (21200); MS (FAB) $m / z$ $671\left([\mathrm{M}+\mathrm{H}]^{+}\right)$. Anal. calcd for $\mathrm{C}_{45} \mathrm{H}_{39} \mathrm{~N}_{2}$ PS: C, 80.57; H, 5.86; N, 4.18; P, 4.62. Found: C, 80.39; H, $5.82 ; \mathrm{N}, 4.11 ; \mathrm{P}, 4.44$.

6: $\mathrm{Mp} 235^{\circ} \mathrm{C} ;{ }^{1} \mathrm{H}$ NMR $\left(\mathrm{CDCl}_{3}, 400 \mathrm{MHz}\right) \delta 1.26(\mathrm{~s}, 6 \mathrm{H}), 1.35$ (s, 6H), 1.72-1.83 (m, 2H), 2.02-2.13 
(m, 2H), 2.40-2.50 (m, 2H), $5.76(\mathrm{br}, 2 \mathrm{H}), 5.98(\mathrm{br}, 2 \mathrm{H}), 6.41(\mathrm{br}, 2 \mathrm{H}), 7.27-7.48(\mathrm{~m}, 13 \mathrm{H}), 7.53(\mathrm{~m}$, $2 \mathrm{H}), 8.68(\mathrm{~m}, 2 \mathrm{H}) ;{ }^{31} \mathrm{P}\left\{{ }^{1} \mathrm{H}\right\} \mathrm{NMR}\left(\mathrm{CDCl}_{3}, 162 \mathrm{MHz}\right) \delta+31.0$; IR $(\mathrm{KBr}) v_{\max } 3414(\mathrm{NH}) \mathrm{cm}^{-1}$; UV/Vis $\left(\mathrm{CH}_{2} \mathrm{Cl}_{2}\right) \lambda_{\max }(\varepsilon): 303$ (25400), 507 (37400); MS (FAB) $m / z 672\left(\mathrm{M}^{+}\right)$. HRMS: Calcd for $\mathrm{C}_{45} \mathrm{H}_{41} \mathrm{~N}_{2} \mathrm{PS}$ $\left(\mathrm{M}^{+}\right), 672.2728 ;$ Found, 672.2734.

Palladium complex 7: A mixture of 5 (34 mg, $0.050 \mathrm{mmol}), \mathrm{Pd}(\mathrm{dba})_{2}(29 \mathrm{mg}, 0.050)$, and $\mathrm{CH}_{2} \mathrm{Cl}_{2}(8$ $\mathrm{mL}$ )was stirred for $3 \mathrm{~h}$ at room temperature. The mixture was then concentrated under reduced pressure, and subjected to silica gel column chromatography (hexane $/ \mathrm{CH}_{2} \mathrm{Cl}_{2} / \mathrm{AcOEt}=10 / 3 / 1$ ). The fraction of $R_{\mathrm{f}}=0.5$ (red-purple band) was collected and washed with $\mathrm{MeOH}$ to give 7 as a purple solid (36 mg, 92\%). The metathesis of $6(9.5 \mathrm{mg}, 0.014 \mathrm{mmol})$ with $\mathrm{Pd}(\mathrm{OAc})_{2}(3.2 \mathrm{mg}, 0.014 \mathrm{mmol})$ in $\mathrm{CH}_{2} \mathrm{Cl}_{2} / \mathrm{MeOH}(2: 1,3 \mathrm{~mL})$ afforded the complex 7 in quantitative yield. $\mathrm{Mp} 255{ }^{\circ} \mathrm{C}(\mathrm{dec}) ;{ }^{1} \mathrm{H} \mathrm{NMR}$ $\left(\mathrm{CDCl}_{3}, 400 \mathrm{MHz}\right) \delta 1.22(\mathrm{~s}, 6 \mathrm{H}), 1.67(\mathrm{~s}, 6 \mathrm{H}), 2.12-2.27(\mathrm{~m}, 1 \mathrm{H}), 2.30-2.44(\mathrm{~m}, 1 \mathrm{H}), 2.48-2.64(\mathrm{~m}$, 2H), 2.77-2.90 (m, 2H), 6.10 (br, 2H), 6.22 (br, 2H), 6.34 (br, 2H), 7.26-7.29 (m, 3H), 7.29-7.32 (m, 4H), 7.32-7.38 (m, 6H), 7.39-7.44 (m, 2H); ${ }^{13} \mathrm{C}\left\{{ }^{1} \mathrm{H}\right\} \mathrm{NMR}\left(\mathrm{CDCl}_{3}, 75 \mathrm{MHz}\right) \delta 14.1,14.2,28.6,29.1$, 29.3, 30.5, 30.6, 31.7, 31.7, 40.5, 40.7, 109.2, 118.6, 119.2, 127.4, 127.7, 128.6, 128.7, 130.3, 130.9, $131.7,132.2,133.3,134.0,134.8,141.5,142.3,154.2,154.4,157.5,157.7 ;{ }^{31} \mathrm{P}\left\{{ }^{1} \mathrm{H}\right\} \mathrm{NMR}\left(\mathrm{CDCl}_{3}, 162\right.$ MHz) $\delta+47.0$; UV/Vis $\left(\mathrm{CH}_{2} \mathrm{Cl}_{2}\right) \lambda_{\max }(\varepsilon): 524$ (14000); MS (MALDI-TOF) $m / z 777\left(\mathrm{M}^{+}\right)$. HRMS: Calcd for $\mathrm{C}_{45} \mathrm{H}_{39} \mathrm{~N}_{2} \mathrm{PPdS}\left(\mathrm{M}^{+}\right)$, 776.1606; Found, 776.1603.

Heck reaction using 7: Typical procedure: $p$-Bromobenzaldehyde (9.25 g, $50 \mathrm{mmol})$, anhydrous sodium acetate $(5.00 \mathrm{~g})$, and Pd complex $7(3.9 \mathrm{mg}, 5.0 \mu \mathrm{mol})$ were placed in a $200 \mathrm{~mL}$ two-necked flask equipped with a reflux condenser. After repeated degassing, triethyleneglycol dimethyl ether (1 $\mathrm{mL}$, internal standard for GC), $N, N$-dimetylacetamide $(50 \mathrm{~mL})$ were injected. $n$-Butyl acrylate (8.6 $\mathrm{mL}, 60 \mathrm{mmol}$ ) was added to the flask at $135^{\circ} \mathrm{C}$, and the resulting mixture was stirred at the same temperature. The consumption of $p$-bromobenzaldehyde was monitored by GC, and the yield of the Heck product was determined by comparison with the internal standard. When the catalytic activity of 7was lost, the color of the solution changed from reddish purple to yellow. 


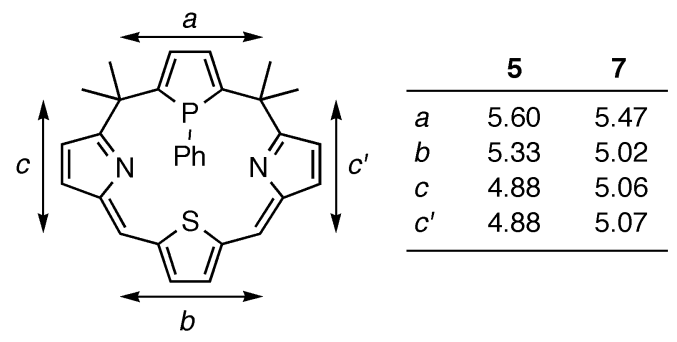

Figure S1. The edge-to-edge distances of 5 and $\mathbf{7 .}$

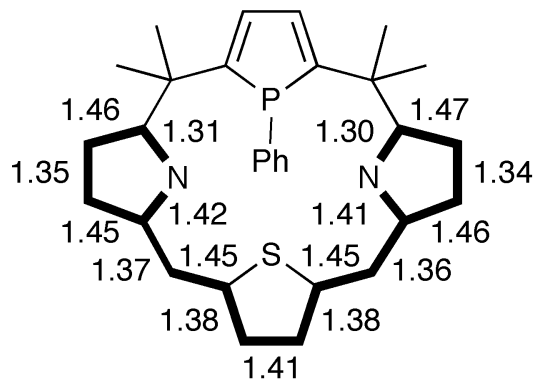

5

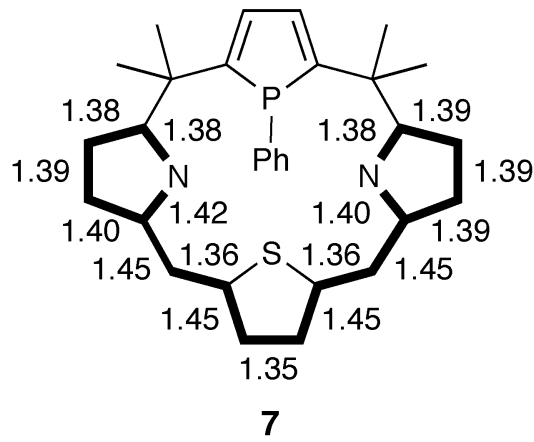

Figure S2. Selected bond lengths ( $\AA$ ) of $\mathbf{5}$ and $\mathbf{7}$.

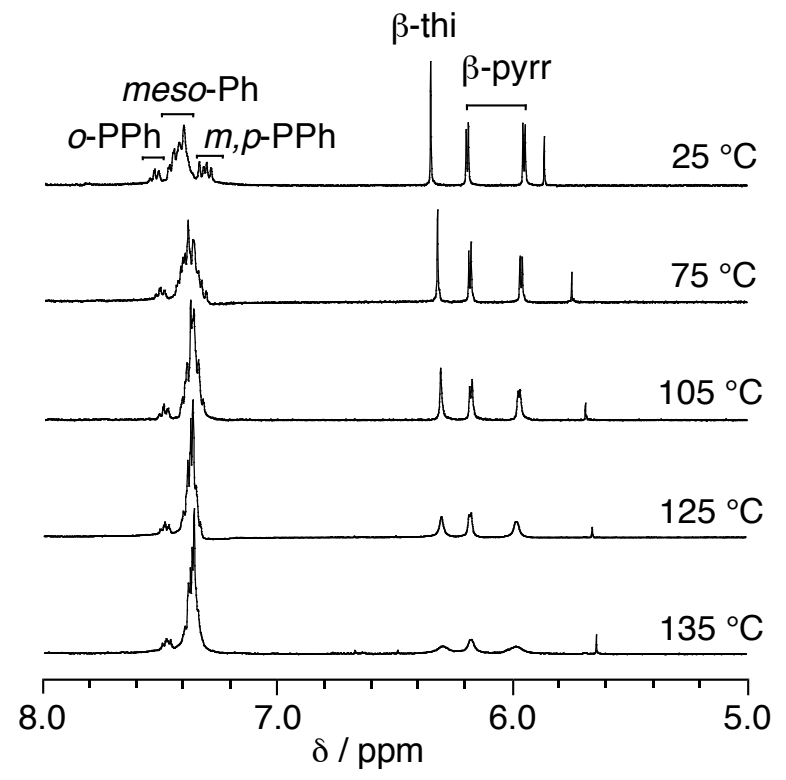

Figure S3. Variable-temperature ${ }^{1} \mathrm{H}$ NMR spectra of 7 in DMA- $d_{9}$. 


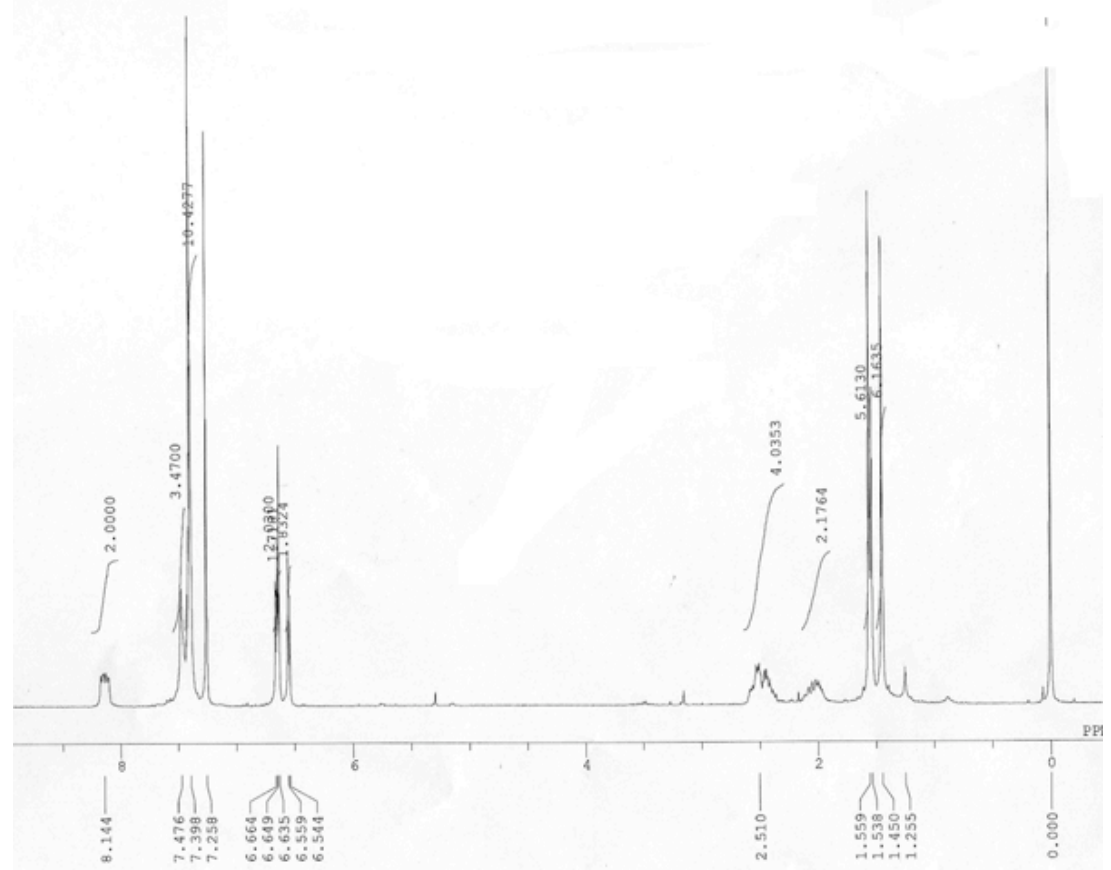

Figure S4. ${ }^{1} \mathrm{H}$ NMR spectrum of $\mathbf{3}$ in $\mathrm{CDCl}_{3}$.

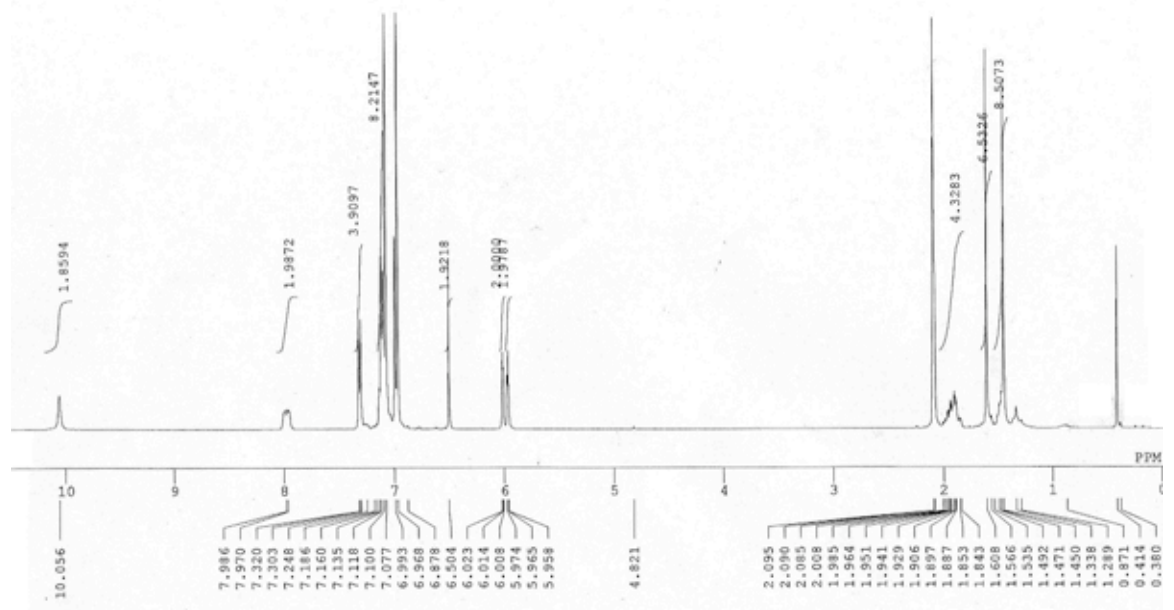

Figure S5. ${ }^{1} \mathrm{H}$ NMR spectrum of 4 in toluene- $d_{8}$ at $70{ }^{\circ} \mathrm{C}$. 


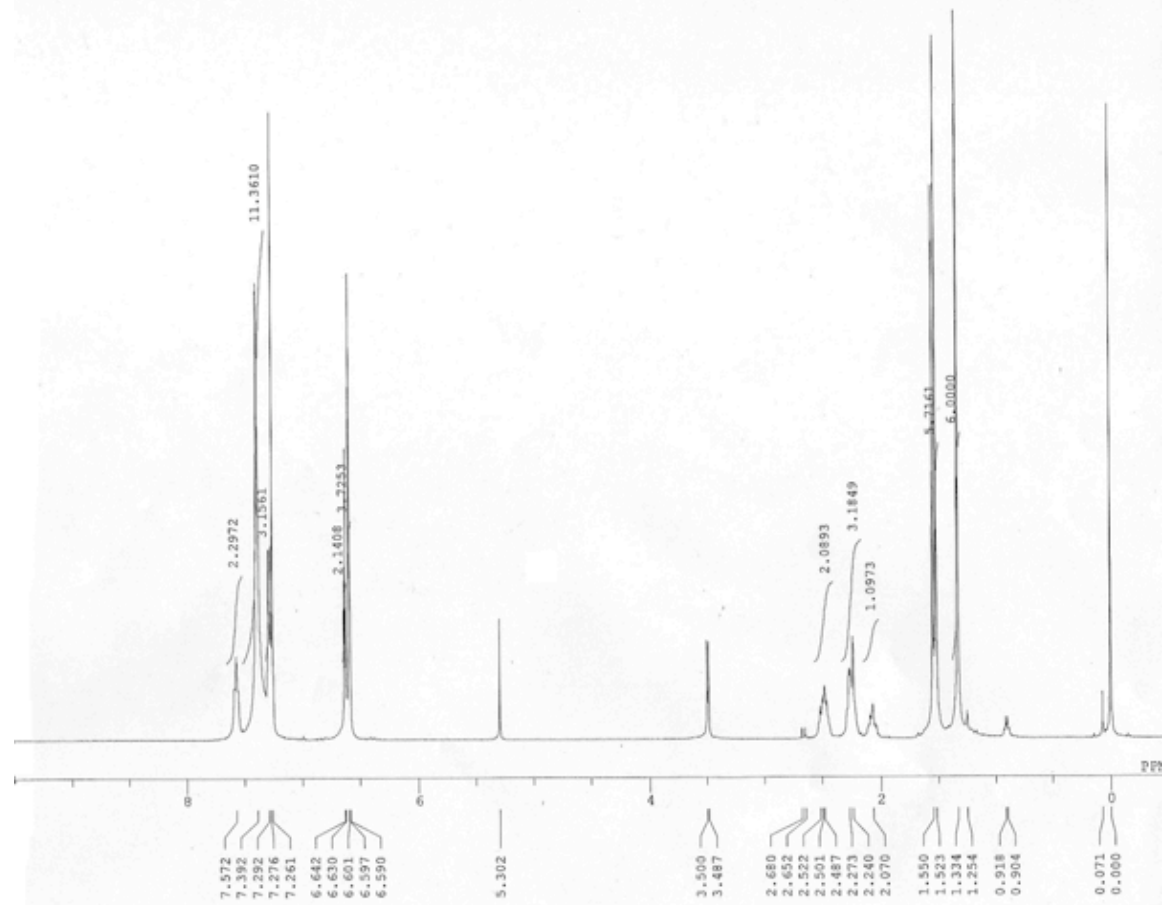

Figure S6. ${ }^{1} \mathrm{H}$ NMR spectrum of 5 in $\mathrm{CDCl}_{3}$.

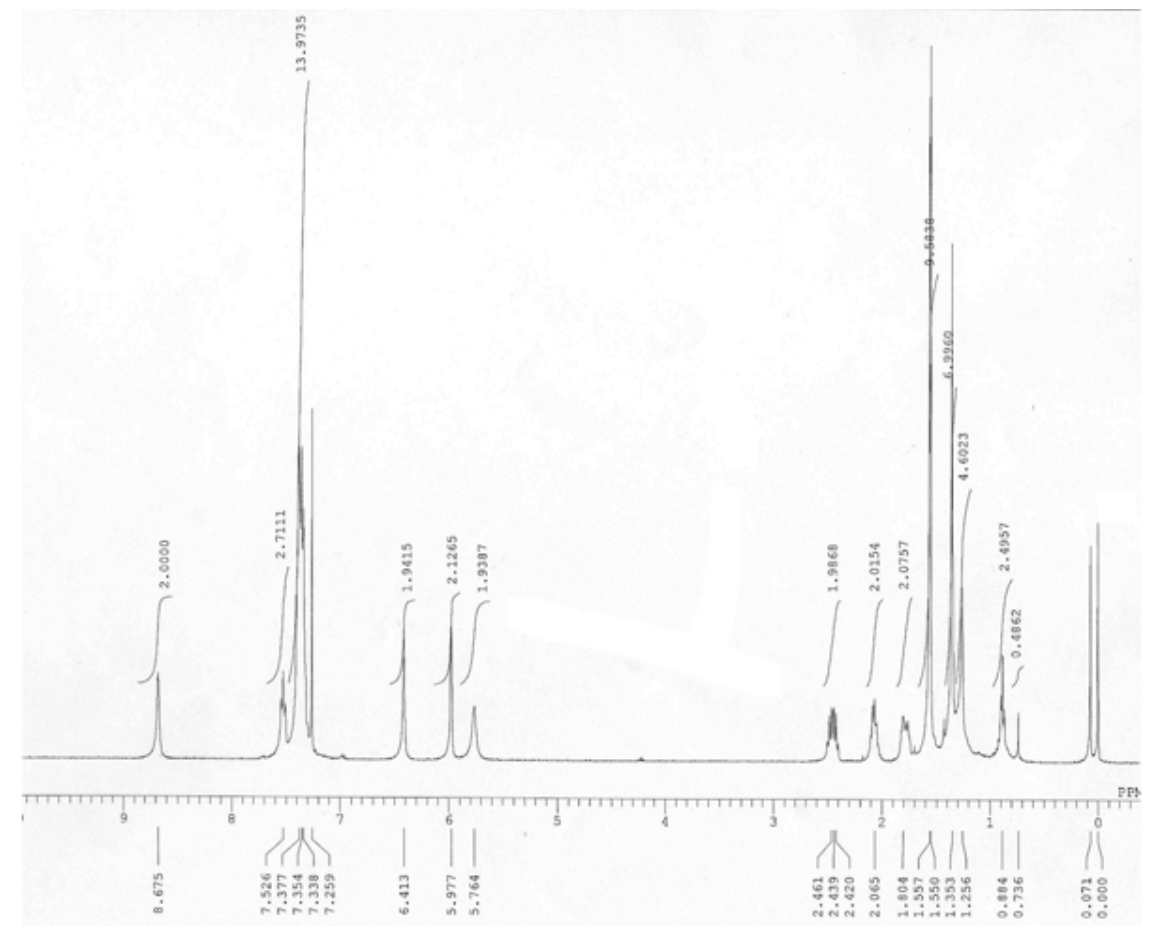

Figure S7. ${ }^{1} \mathrm{H}$ NMR spectrum of $\mathbf{6}$ in $\mathrm{CDCl}_{3}$. 


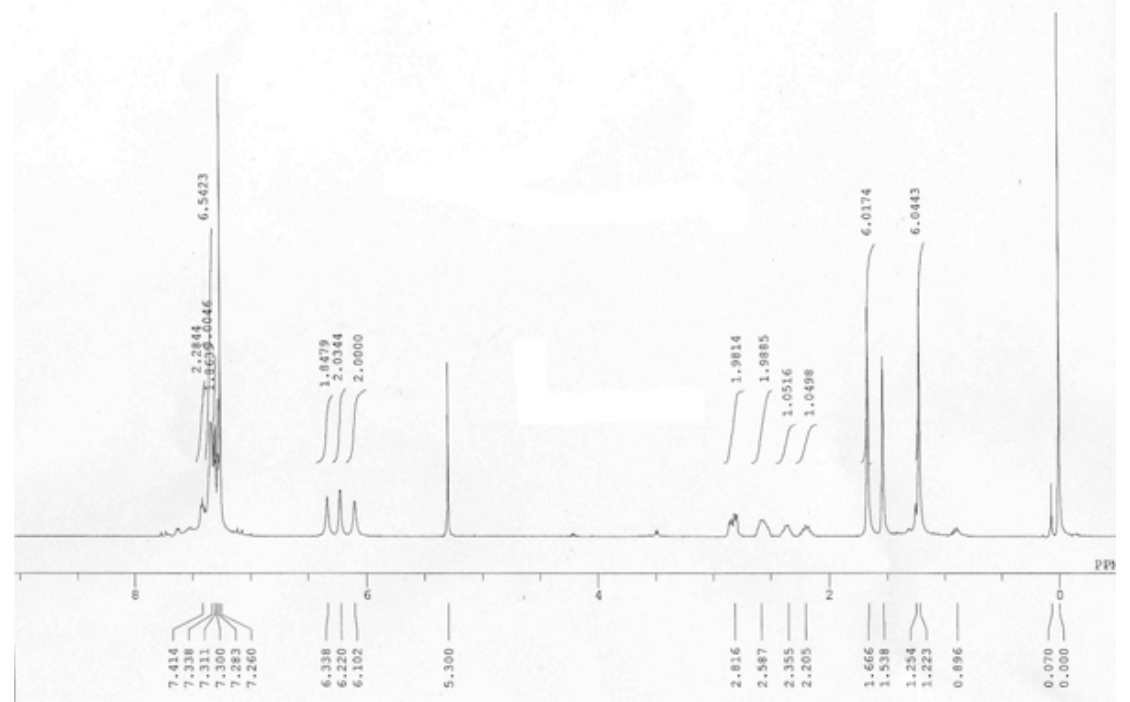

Figure S8. ${ }^{1} \mathrm{H}$ NMR spectrum of 7 in $\mathrm{CDCl}_{3}$.

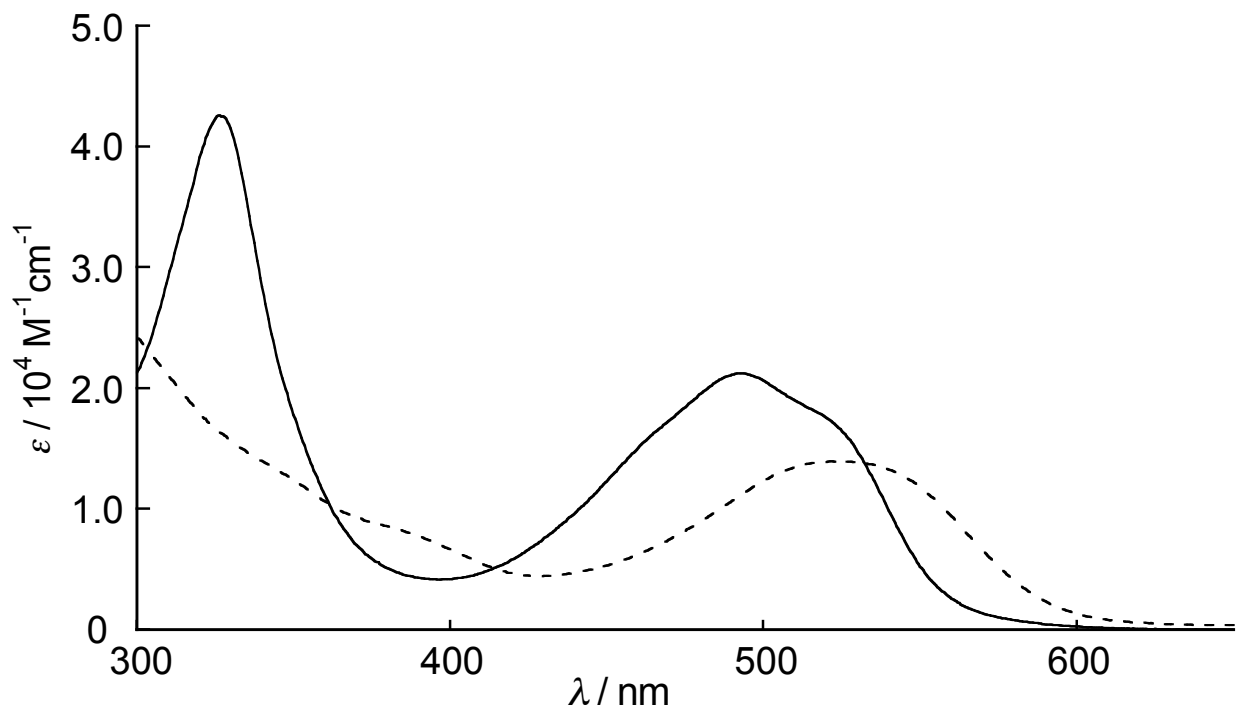

Figure S9. UV-Vis absorption spectra of $\mathbf{5}$ (solid line) and $\mathbf{7}$ (dotted line) in $\mathrm{CH}_{2} \mathrm{Cl}_{2}$. 


\section{Density Functional Theory (DFT) Calculations on Model Complexes}

To get more insight into the formal oxidation state of the palladium center in 7 , we carried out DFT calculations of complexes $\mathbf{8}$ and $\mathbf{9}$, where the complexes $\mathbf{8}$ and $\mathbf{9}$ were adopted as a model for $\mathbf{7}$ and a $\mathrm{Pd}(\mathrm{II})$ reference, respectively (see Figure S10 for $\mathbf{8}$ and $\mathbf{9}$ ). In the DFT calculations, the B3LYP functional ${ }^{3}$ was used for exchange-correlation term and LANL2DZ ${ }^{4}$ and $6-31 \mathrm{G}(\mathrm{d})^{5}$ basis sets were employed for Pd and the other atoms, respectively. The Gaussian 03 program package ${ }^{6}$ was used in all these calculations and the MOLEKEL program ${ }^{7}$ was employed to draw picture of molecular orbital. Except for hydrogen, the geometry of $\mathbf{8}$ was taken to be the same as the experimentally geometry of $\mathbf{7}$, while the positions of the hydrogen atoms of $\mathbf{8}$ were optimized by the molecular mechanics with universal force field (UFF). ${ }^{8}$ The geometry of 9 was optimized with the DFT method. The natural

3 (a) Becke, A. D. Phys. Rev. A 1988, 38, 3098. (b) Becke, A. D. J. Chem. Phys. 1993, 98, 5648. (c) Lee, C.; Yang, W.; Parr, R. G. Phys. Rev. B 1988, 37, 785.

${ }^{4}$ Hay, P. J.; Wadt, W. R. J. Chem. Phys. 1985, 82, 299.

${ }^{5}$ (a) Hehre, W. J.; R. Ditchfield, R.; Pople, J. A. J. Chem. Phys. 1972, 56, 2257. (b) Francl, M. M.; Pietro, W. J.; Hehre, W. J.; Binkley, J. S.; Gordon, M. S.; DeFrees, D. J.; Pople, J. A. J. Chem. Phys. 1982, 77, 3654.

${ }^{6}$ Frisch, M. J.; Trucks, G. W.; Schlegel, H. B.; Scuseria, G. E.; Robbins, D. J.; Cheeseman, J. R.; Montgomery, J. A., Jr.; Vreven, T.; Kudin, K.; Burant, J. C.; Millam, J. M.; Iyenger, S. S.; Tomasi, J.; Barone, V.; Mennucci, B.; Cossi, M.; Scalmani, G.; Rega, N.; Petersson, G. A.; Nakatsuji, H.; Hada, M.; Ehara, M.; Toyota, K.; Fukuda, R.; Hasegawa, J.; Ishida, M.; Nakajima, T.; Honda, Y.; Kitao, O.; Nakai, H.; Klene, M.; Li, X.; Knox, J. E.; Hratchian, H. P.; Cross, J. B.; Adamo, C.; Jaramillo, J.; Gomperts, R.; Stratmann, R. E.; Yazyev, O.; Salvador, A.; Dannenberg, J. J.; Zakrzewski, V. G.; Dapprich, S.; Daniels, A. D.; Strain, M. C.; Farkas, O.; Malick, D. K.; Rabuck, A. D.; Raghavachari, K.; Foresman, J. B.; Ortiz, J. V.; Cui, Q.; Baboul, A. G.; Clifford, S.; Cioslowski, J.; Stefanov, B. B.; Liu, G.; Liashenko, A.; Piskorz, P.; Komaromi, I.; Martin, R. L.; Fox, D. J.; Keith, T.; Al-Laham, M. A.; Peng, C. Y.; Nanayakkara, A.; Challacombe, M.; Gill, P. M. W.; Johnson, B.; Chen, W.; Wong, M. W.; Gonzalez, C.; Pople, J. A. Gaussian 03; Gaussian, Inc.: Pittsburgh, PA, 2003.

${ }^{7}$ Flükiger, P.; Lüthi, H. P.; Portann, S.; Weber, J. MOLEKEL v.4.3 for Scientific Computing, Manno, Switzerland, 2000-2002. Portman, S.; Lüthi, H. P. CHIMIA 2000, 54, 766.

${ }^{8}$ Rappé, A. K.; Casewit, C. J.; Colwell, K. S.; Goddard III, W. A.; Skiff, W. M. J. Am. Chem. Soc. 1992, 114, 10024. 
atomic orbital (NAO) occupancies ${ }^{9}$ of $\mathbf{8}$ and $\mathbf{9}$ are summarized in Figure S10. The NAO occupancy of the $\mathrm{d}_{\mathrm{x}^{2}-\mathrm{y}^{2}}$ orbital was calculated to be $1.259 \mathrm{e}$ in $\mathbf{8}$, which is almost the same as the corresponding value (1.261e) of the reference Pd(II) complex 9. Also, the LUMO of $\mathbf{8}$ consists of the $\mathrm{d}_{\mathrm{x}^{2}-\mathrm{y}^{2}}$ orbital similar to that of 9 (see Figure S10), while the $\pi^{*}$ orbital of the phosphole moiety somewhat mixes into the LUMO probably to reduce the anti-bonding overlap of the P lone-pair with the $d_{x^{2}-y^{2}}$ orbital. The other four $\mathrm{d}$ orbitals are involved in occupied molecular orbitals of both $\mathbf{8}$ and $\mathbf{9}$. These results strongly support that the palladium center takes +2 oxidation state in $\mathbf{7}\left(\mathbf{7}^{\prime}\right)$ in a formal sense.

(a)

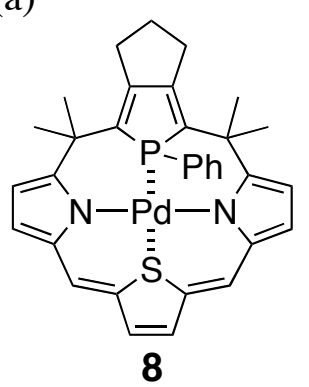

(b)

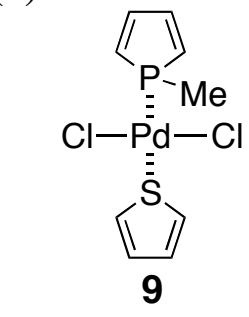

\begin{tabular}{cc}
$d$-orbital & NAO occupancy \\
\hline$d_{\mathrm{xy}}$ & 1.962 \\
$d_{\mathrm{xz}}$ & 1.978 \\
$d_{\mathrm{yz}}$ & 1.962 \\
$d_{\mathrm{x} 2-\mathrm{y} \mathbf{2}}$ & $\mathbf{1 . 2 5 9}$ \\
$d_{\mathrm{z} 2}$ & 1.936 \\
\hline
\end{tabular}

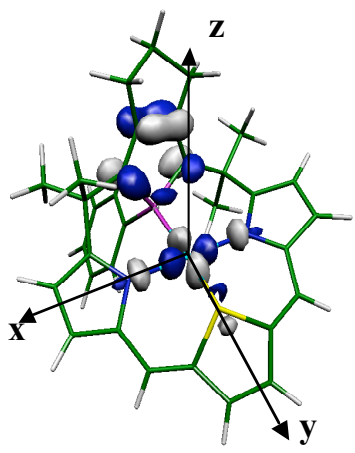

\begin{tabular}{cc}
$d$-orbital & NAO occupancy \\
\hline$d_{\mathrm{xy}}$ & 1.976 \\
$d_{\mathrm{xz}}$ & 1.997 \\
$d_{\mathrm{yz}}$ & 1.968 \\
$\boldsymbol{d}_{\mathrm{x} 2-\mathrm{y} 2}$ & $\mathbf{1 . 2 6 1}$ \\
$d_{\mathrm{z} 2}$ & 1.959 \\
\hline
\end{tabular}

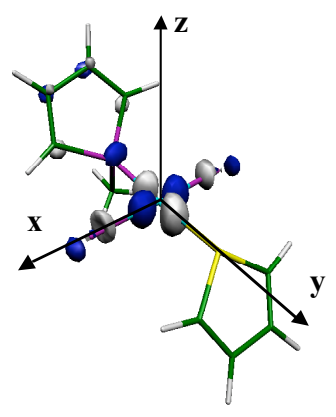

$\mathrm{R}(\mathrm{Pd}-\mathrm{P})=2.275 \AA$

$\mathrm{R}(\mathrm{Pd}-\mathrm{Cl})=2.368 \AA$

$\mathrm{R}(\mathrm{Pd}-\mathrm{S})=2.512 \AA$

Figure S10. The NAO occupancies and the LUMOs of (a) 8 and (b) 9.

\footnotetext{
${ }^{9}$ Reed, A. E.; Curtis, L. A.; Weinhold, F. Chem. Rev. 1988, 88, 849, and references therein.
} 